\title{
SOME PROBLEMS ON THE ELEMENTARY SCHOOL AND JUNIOR HIGH SCHOOL IN A PLANNED NEW HOUSING WHICH ALSO INCLUDE THE PUPILS OF THE SCHOOL DISTRICT OF ITS ENVIRONS.
}

\author{
Hirokuni TANIGUCHI*
}

\section{§ 1. Introduction}

A housing is not only a mass of concrete and mortar, but the place where people will take their life through their mental and physical activities.

On the constructing of the large scale planned new housing, it is of course necessary to establish the public facilities for its housing. The elementary school and junior high school are one of the most important buildings in these many facilities of the educational services.

At present in Japan, small or middle scale planned new housings have been generally constructed in a city or suburbs districts of the city, so it is impossible to disregard a resiprocal relation between a planned new housing and old in its environs. For this problems it will be able to say the same things when large scale redevelopement will be held in a city or town in the near future. Any way, now, from the economical and managing point, in the case of the middle scale new housing (500 1000 houses) it is generally difficult to build an elementary school for the children only who live there. And even in a large scale housing or a new town including more than $50 \sim 60$ thousands houses, it is impossible to disregard the relation between the new housing and its environs for the plan of school. Accordingly it is desirable to develope new community in mixing new and old housing though there are still left some problems on this district planning.

Depend on my some previous studies, it is recognized that an association of pupils through the elementary school or junior high school has a more powerful possibility in several other regional facilities to promote the progressive development of communication between the new and old housing.

This report comprises mainly that analysis of the most reasonable ratio of pupils number of the planned new and old housing in one class at the elementary or the junior high school in the planned new housing with their mutual selection of friends and in relation it, some comparative studies about the characters and the kinds of play of these two different districts.

Table 1 .

\begin{tabular}{l|c|r|r|r|r|r|r}
\hline & & \multicolumn{3}{|c|}{ School Years } & \multicolumn{2}{c}{ Averege Content Ratio } \\
\hline & - & $1 \mathrm{st}$ & $2 \mathrm{nd}$ & $3 \mathrm{rd}$ & & & \\
Shiroyama & Classes & 9 & 6 & 5 & $1 \mathrm{st}$ & $2 \mathrm{nd}$ & $3 \mathrm{rd}$ \\
Junior High & $m$ & 175 & 162 & 170 & 0.274 & 0.175 & 0.194 \\
School & $f$ & 164 & 129 & 116 & 0.296 & 0.295 & 0.306 \\
& Sum & 339 & 291 & 286 & - & - & - \\
\hline Jiyuugaoka & - & $1 \mathrm{st}$ & $2 \mathrm{nd}$ & $3 \mathrm{rd}$ & $4 \mathrm{th}$ & $5 \mathrm{th}$ & $6 \mathrm{th}$ \\
Elementary & Classes & 4 & 2 & 4 & 4 & 4 & 4 \\
School & Pupils & 165 & 119 & 173 & 167 & 200 & 196 \\
& $\bar{C}$ & 0.610 & 0.623 & 0.582 & 0.692 & 0.700 & 0.749 \\
\hline Shiga & - & $1 \mathrm{st}$ & $2 \mathrm{nd}$ & $3 \mathrm{rd}$ & 4 th & 5 th & 6 th \\
Elementary & Classes & 3 & 3 & 3 & 4 & 4 & 2 \\
School & Pupils & 149 & 153 & 178 & 178 & 120 & 104 \\
& $\bar{C}$ & 0.168 & 0.149 & 0.231 & 0.231 & 0.206 & 0.105 \\
\hline
\end{tabular}

A summary of subjects of survey ('59'61)

1) City of Nagoya; Kinjo Elementary School in Siga Housing ( $\mathrm{J}-\mathrm{H}-\mathrm{C}$ )

2) City of Nagoya; Higashiyama Elementary School in Hoshigaoka Housing $(\mathrm{J}-\mathrm{H}-\mathrm{C})$

3) City of Nagoya; Jiyugaoka Elementary School in Chigusadai Housing (City of Nagoya)

4) City of Nagoya; Shiroyama Junior High School in Chigusadai Housing (City of Nagoya)

For all pupils of above mentioned their

companionship, group cohesien, zone of play, school recored, and personality were surveied. The number of pupils, classes teachers and schools area (scale) are as following table 1.

* Assistant, Architectural Department in Tokyo Institute of Technology

(Received on Feb. 25, 1963. All Commpications and Discussion until Sept. 31, 1963) 


\section{\$ 2. On the selection of friends by pupils in one class}

The selection of friends by pupils is owing to the many incentives and causes in their life. And in these many causes, especially the selection of friends in the school class unit holds the importnat part.

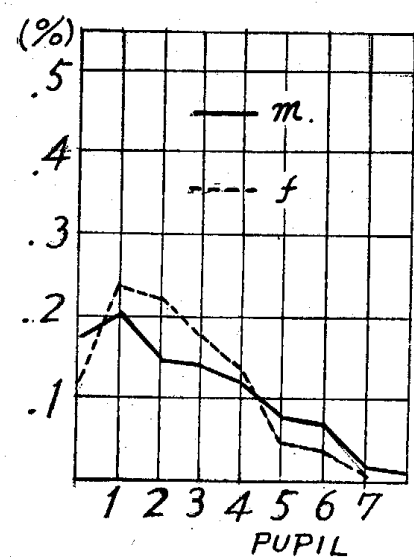

Fig. 1. Distribution of pupils number in one selected group in distinction from sex.
Then each pupil was made to select their about six* familier friends from their belonging class under a half restriction. IIn consequence, from the point of view of the distribution of pupil's number in one selected group in distinction from sex and school year in each school, Fig. 1 shows that the peak of distribution is one or two pupils and it is able to find the same pattern for boys and girls in this figure. And also by the distinction of the school year, there is a difference of distribution.

In general, if these selections are freely permitted to " $r$ " pupils, the probability of this selection is $r /(n-1)$. Therefore the cases of probability: a certain pupil " $J$ " is selected by nobody one pupil and " $r$ " pupils in general, are corresponded with each term of binominal distribution as follows.

$$
(p+q)^{N-1} \quad \text { wherein } p=\frac{r}{N-1} \quad q=1-p
$$

but $N:$ Number of pupils in one class

$r:$ Number of pupils to be selected

then, the probability to be not selected;

$$
p_{0}=\left(\frac{N-1-r}{N-1}\right)^{N-1}
$$

the probability to be selected from just one pupil

$$
p_{1}=(N-1)\left(\frac{r}{N-1}\right)^{N-2}
$$

in general, the probability to be selected from just " $r$ " pupils

$$
p_{r}(N \cdot p \cdot r)=\frac{(N-1) \cdots(N-r)}{r} \cdot\left(\frac{r}{N-1}\right)^{r} \cdot\left(\frac{N-1-r}{N-1}\right)^{N-1-r}
$$

After all, it is noticed that the probability of a certain pupil " $J$ " to be selected by " $r$ " pupils in one class is the total of the each term.

$$
P_{r}=\sum_{r=1}^{r} p(N \cdot p \cdot r)
$$

Then, from the point of relation between a selected group and ratio of children of new housing in its, if this character is analized it will be as follows.

If a certain school class consists of " $N$ " pupils whom including the children of the planned housing, and if this mixing will be held at random, the distributive density of number of pupils of the planned housing who will be included into each group being made by the limitting selection to " $r$ " pupils is approximate as follows by the hypergeometric distribution.

And it is :

$$
p(k=x)=\frac{{ }_{N} C_{k} \cdot{ }_{N-n} C_{r-}{ }^{q}}{{ }_{N} C_{r}}=\frac{N !(N-1) !(N-r) ! r !}{N !\left(n_{d}-k\right) !(r-k) !\left(N-n_{d}-r+k\right) ! k !}
$$

wherein, $N:$ Number of pupils of one class

$n_{d}$ : Number of pupils of planned new housing in one class

$r$ : Number of pupils in one group being made by selection

$k$ : Number of pupils of planned housing in one group.

From the results of calculation on the each class by the above mentioned formula, it is able to get the theoretical distribution as Fig. 2 short dash line (School distinction- elementary school, junior high school and sex distinction) but its curve is different from the real distribution (continuous line).

* The reason why the number of pupils who will be selected is fixed at 6 pupils is as follows. On the preliminary surbey, though it is permitted to select very freely, the highest peak is 6 friends whom a pupils selected and in the another study (sociometry and its theory) the similar result is also found. 


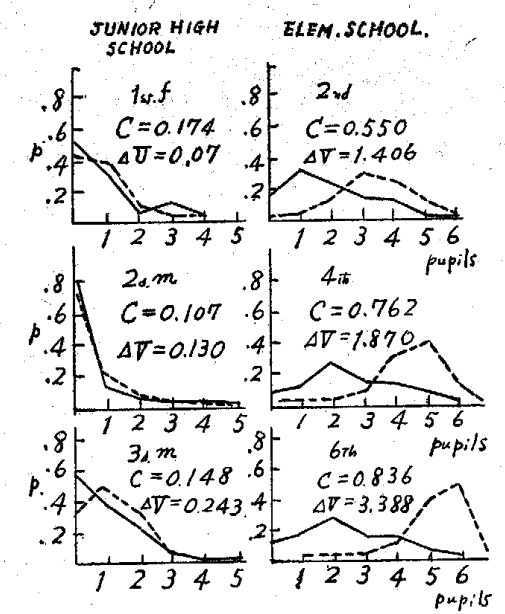

Fig. .2 Real distribution and theoretical distribution.

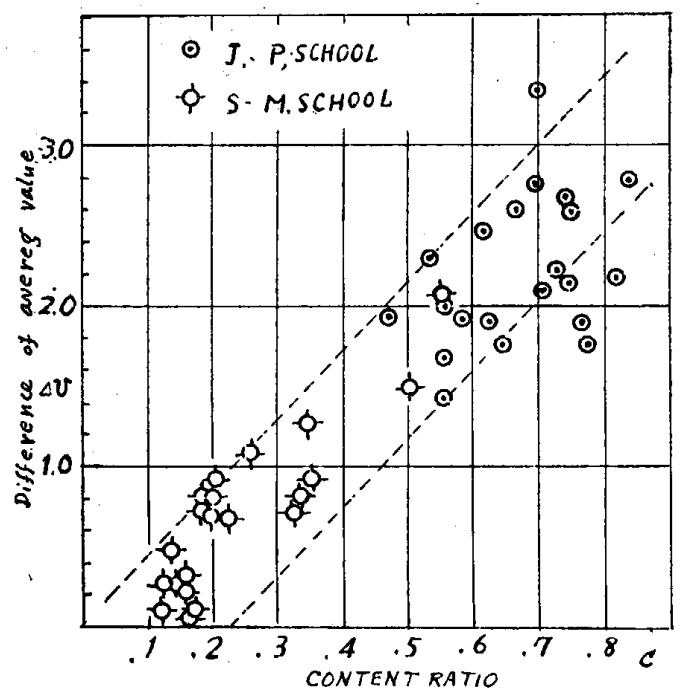

Fig. 3. Difference of averege value $(\Delta V)$ and content ratio of children of new housing in one class.
The causes of this difference is considered as following problems.

i) Each pupil does not always select all of the specified pupils number of selection.

ii) The consciousness of selection by pupil is symbolic and this selection was not done at random mathematically between the pupile of planned new housing and its environs.

For these two problems, the first problem is general phenomenon as the actual matter of the social psycology, it will be psycological index for the selection of friends. The second problems will be here an important point concerning with the special character of communication between the children of the planned housing and its environs.

It should be here consider, with the theory of probability, that above subjects. Therefore with the intention of analysis in the difference of the actual distribution and theoretical one, the mutual relation of the difference $(A V)$ of average value of each distribution and the content ratio of children of planned housing in one school class, the difference of this average also more increases as in Fig. 3. This phenomenon, distinctly is caused by the influence of the children of planned housing. And an existential probability of children of the housing in a group by selection is not influenced with the mathematical distribution but with the more psychological consciousness, and these tendency are the more appear the more increase children of housing. In the case of junior high school the relation of the content ratio of the pupils of new housing in one class and the content ratio in the mutual selections are roughly linear dirtribution. After all, considering

from the point of view of the mutual selection, it will be done, compearing with the content ratio, more naturaly not symbolicaly or not consciously than the case of the unilateral selection.

\section{§ 3. On the contnent ratio and cohesion of pupils in one class of school.}

Considering for one school class, though there are many methods of education for it, to enhance the level of all pupils in the class homogeniously will be one of the desirable purposes of school education. Then, there are the expective possibilities of good results by the mutual influence, which pupils have their friendship closely and cultural exchanges between the planned new housing and its environs. The grade of cohesion will be one condition of programming in the school educations.

In sociometric matrix, the distribution of the selection of friend in each class existis in following all zone or some zone in any case as Fig. 5. Namely these zone are as i) iv).

i ) $(d-d)$ Zone : The case of that the children of the new housing select the children of the same housing.

ii) $(d-s)$ Zone: The case of that the chlidren of new housing select the children of its environs. iii) $(s-d)$ Zone : The case of that the children of its environs select the children of new housing. iv) $(s-s)$ Zone : The case of that the children of its environs select the children of the same district. In each case, the proportion of density of the existence of the selected pupil is different by the mixing proportion (content ratio) of children of new housing and its environs in one class. In a class which consists of " $N$ " pupils and under the condition that will be permitted to select till " $r$ " pupils, if now the selection will be done entirely at random, this proportion of density of the existence of the selected pupil coincides nearly with the proportion of the existential possible number in each case. Namely the proportion of the existent possible number $: d-d: d-s: s-d: s \rightarrow s$ is 

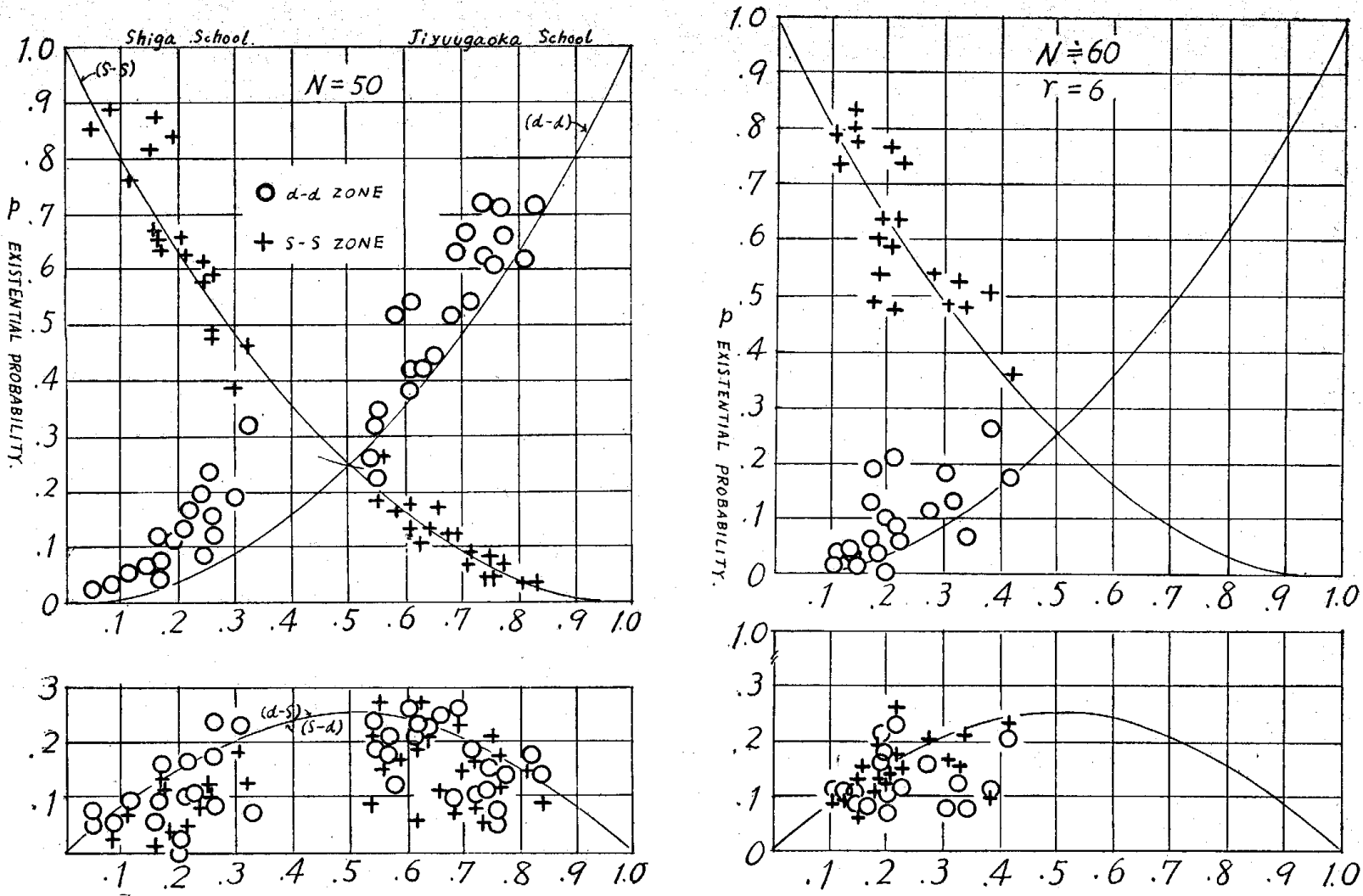

C : CONTENT RATIO

S. \& J. ELEMENTARY SCHOOL

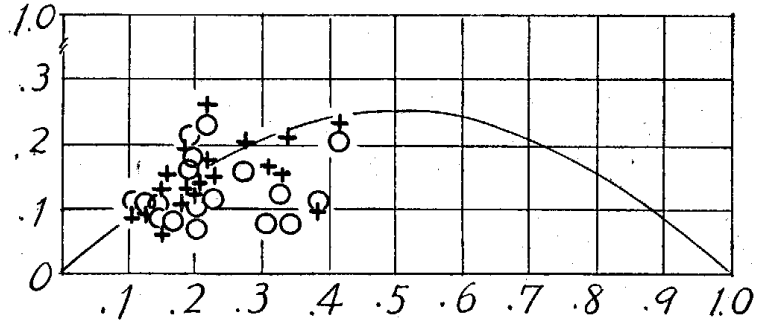

C : CONTENT RATIO

SHIROYAMA JUNIOR HIGH SCHOOL.

Fig. 4. proportion of existent possible number $(\doteqdot$ existential density $)$ and content ratio.

$d-d: d-s: s-d: s-s=\frac{n_{d}\left(n_{d-1}\right)}{N(N-1)}: \frac{n_{d} \cdot n_{s}}{N(N-1)}: \frac{n_{s} \cdot n_{d}}{N(N-1)}: \frac{n_{s} \cdot\left(n_{s}-1\right)}{N(N-1)}$

wherein,

$$
N=n_{d}+n_{s} \quad C=\frac{n_{d}}{N}
$$

$N_{d}$ : Number of children of new housing

$N_{s}$ : Number of children of its environs

$N$ : Number of children in one class

$C$ : Content ratio of children of new housing

$r:$ Number of selected pupil with a limit.

Therefore, for instance, in the case of $(d-d)$, the number of selected pupil is given about with the following formula.

$$
N_{d-d}=r \cdot N \cdot \frac{n_{d} \cdot\left(n_{d}-1\right)}{N(N-1)}=\frac{r \cdot C \cdot N \cdot(C N-1)}{N-1}
$$

Making this proportion of the existent possible number the proportion of existent density, a relation of these four cases is shown with a curve in the Fig. 4.

And it is each distribution (o, +) of Fig. 4-1 that the proportion of the selected pupil's number in each case and of all selected pupil's number in matrix which is gotten from the real survey result is culculated and inserted in. (the case of elementary school).

Observing the relation of this distribution and theoretical curve, it is said as follows.

1) In the distribution of $d-\mathrm{d}$ zone, $95 \%$ of all shows higher value than the theoretical value.

2) The distribution of $s-s$ zone is distributive nearly with an axis of theoretical value except $c<0.2$

$3)$ At the relation of character 1$)$ and 2). the distribution of cases of $(d-s)$ and $(s-d)$ is almost lower value than the theoretical value, in general. Especially at $c<0.5$, this character is evidently appeared. As above mentioned, it is found the tendency that the children of new housing select the children of the same district indeed as Fig. 5 in the distribution has a thendency as $\leftarrow$. Especially at $c<0.2 \sim 0.3$, the tendency that the children of both districts select each other the children who belong to the same district 


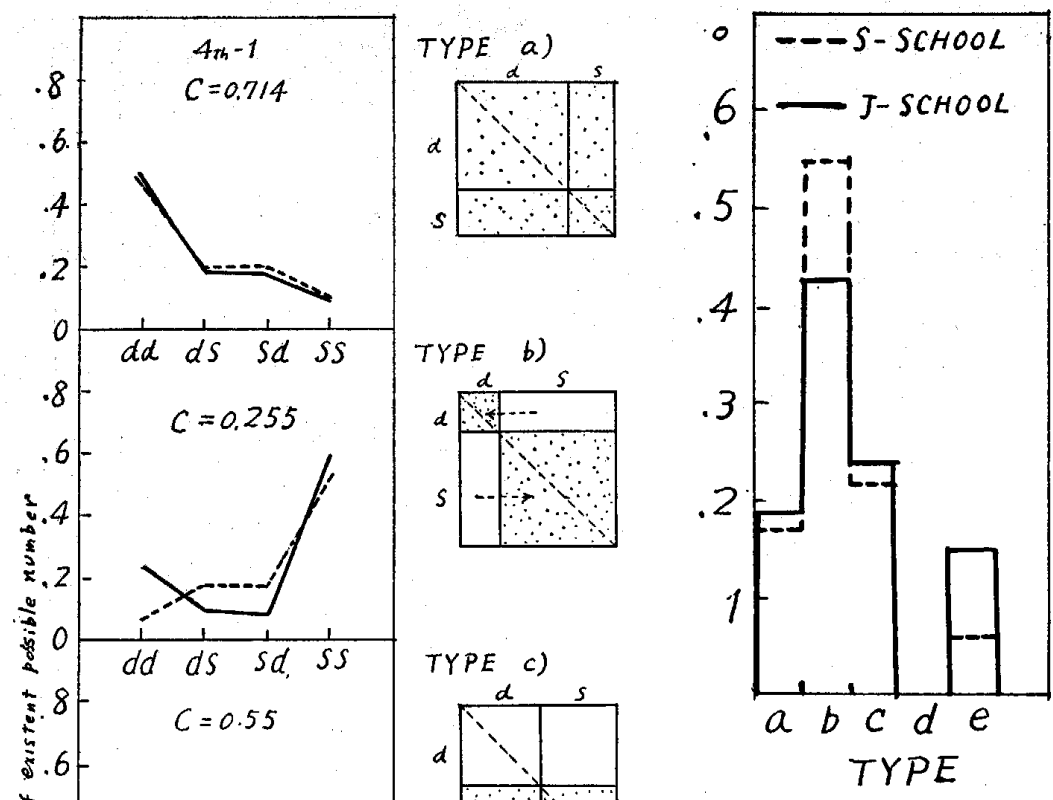

Fig. 6. $\%$ of existence of each type.

tendatively as follows.

a) Uniform Type

b) Type of concentration of the selecting from the same district.

c) Transversal distribution type

d) Type of concentration of selecting from the different distrct.

e) Longitudinal distribution type

Each type above mentioned is shown as Fig. 5 .

Fig. 5. Distribution type ng with children in a same district is recongnized here. As " $C$ " value is higher it seems this tendency goes weak, especially the children of its environs select their friends at random.

From the point of view of the class distinction, the graph of the proportion density of the distinction of each case is gotten by the each content ratio in this class. This typical form (-- line) is (shown as Fig. 5) able to compare with a straight line of real distributive density. The difference is similitude to the distributing type of matrix, and is able to classify into about a) e) type. And they are called

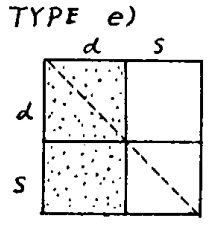

is strong. Namely the groupnizi-

Classifying the distribution of each class into any these cases, b) type is most, and it holds about $60 \%$ of all. (Fig. 6) For the case of junior high school, it is also recognized the character as above mentioned.

Now there are some theoretical proposals to evaluate the strength of combination of pupil in one group, on sociometry in social psycology. For in stance :

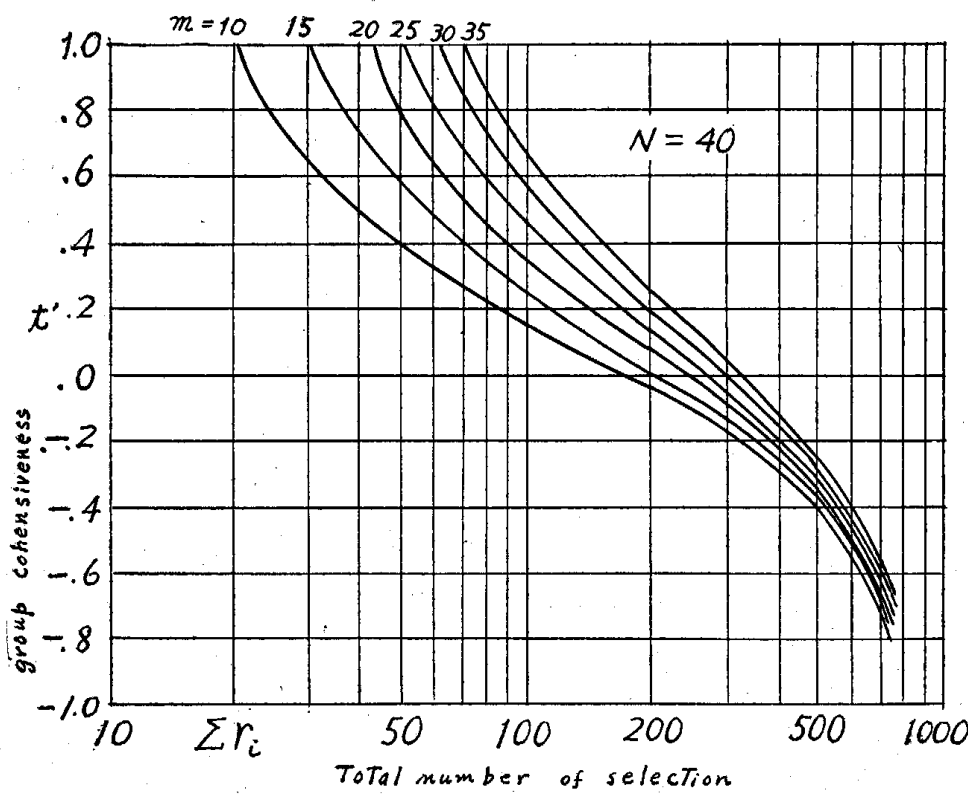

Fig. 7. Index of group cohesiveness $\left(t^{\prime}\right)$ and total number of selection $\left(\Sigma r_{i}\right)$.
1) Index of group expansiveness

$$
E=\frac{C}{N}
$$

2) Index of group coherence

$$
\begin{array}{r}
I_{c c}=\frac{R q}{U p} \ldots \ldots \ldots \ldots \ldots \ldots \ldots \ldots \ldots \ldots \\
\quad \therefore p=\frac{r}{N-1} q=1-p
\end{array}
$$

3) Index of group cohesion

$$
\mathrm{C}_{0}=\frac{R}{C_{2}^{N}} \text { or } C_{0}=\frac{2 R}{r N}
$$

4) Index of group cohensiveness

$$
t^{\prime}=\frac{2 N(N-1) m-\left(\sum r_{i}\right)^{2}}{\sum r_{i}\left[N(N-1)-\sum r_{i}\right]}
$$

$N$ : Number of group people

$C$ : Number of selection

$R:$ Number of mutual selection

$U$ : Number of unilateral selection

$r$ : Number of permitted selection 


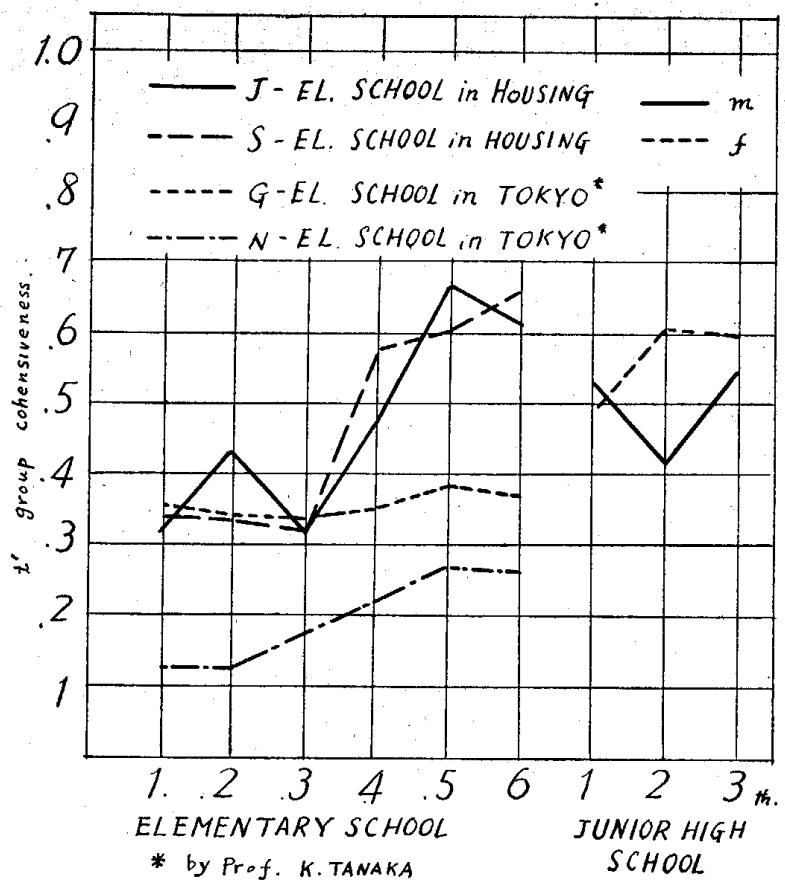

Fig. 8. Group cohesiveness and school years. $r:$ Number of permitted selection

(Leo Katz \& J.H. Powell) (approximation)

$m:$ Number.or mutural selection

$\Sigma r_{i}$ : Total number of selection

For instance on the formula $t^{\prime}$ as for $N=40$, it will be as Fig. 7 according to the writer's culculation. In general, this each value has tendency of arising in proportion as being higher school year class. Especially as for " $t$ " " in the elementary schools of new housing, the rising ratio of " $t$ "' in propotion as to school year is higher than the value of " $t$ "' of general elementary school and also there is clearly difference of value " $t$ " between in lower years and in higher years as Fig. 8. It is considerable that this phenomenon is a special feature of the mixed class containing the pupils of the new housing and its environs. Namely it seems a kind of symptom of symbolic friends selection on growing up of children. Therefore it is thinkable that this result will be one of the most important conditions to emphasize the necessity of separation of the facilities for the education and the management of school. And also in an educational field, it is said that the class of very lower school years (1st-2nd grade) shoud be separated from the classes of 3rd-6th grade for the effective education and for difference owing to the growth of children. However junior high school have no such phenomenon as above mentioned.

Taking the mutual relation to the content ratio of pupils of new housing in one class and to the each value of $E, \mathrm{I}_{c c} t^{\prime}$, it is not found the character of corelation between $E$ and $I_{c c}$, but is able to find the relation about " $t$ "' as the Fig. 9-1.

Fig. 9, shows the distribution for the classes of higher school years in the elementary school and in the junior high school. This graph is considered as the wave form scatter that seems to take a maximum value at $c \doteqdot 0.3$ and $C \doteqdot 0.7$ but minimum value at $C \doteqdot 0.5$ about value $\mathrm{t}^{\prime}$ (case sf 4 th-6th school year etc.). Namely this waveform scatter means that the case of $C \doteqdot 0.3$ or 0.7 about content ratio of pupils of housing in one class will be the maximum value of group cohesiveness. Especially in the case of $C \doteqdot 0.7$, it will depend on the influence of the absolute majority of children of new housing but in case $C \doteqdot 0.3$ depend on children of old housing. For Fig. 9-2, it is shown the distribution for the lower grade from the 1st to $3 \mathrm{rd}$ in elementary school. But the distribution of
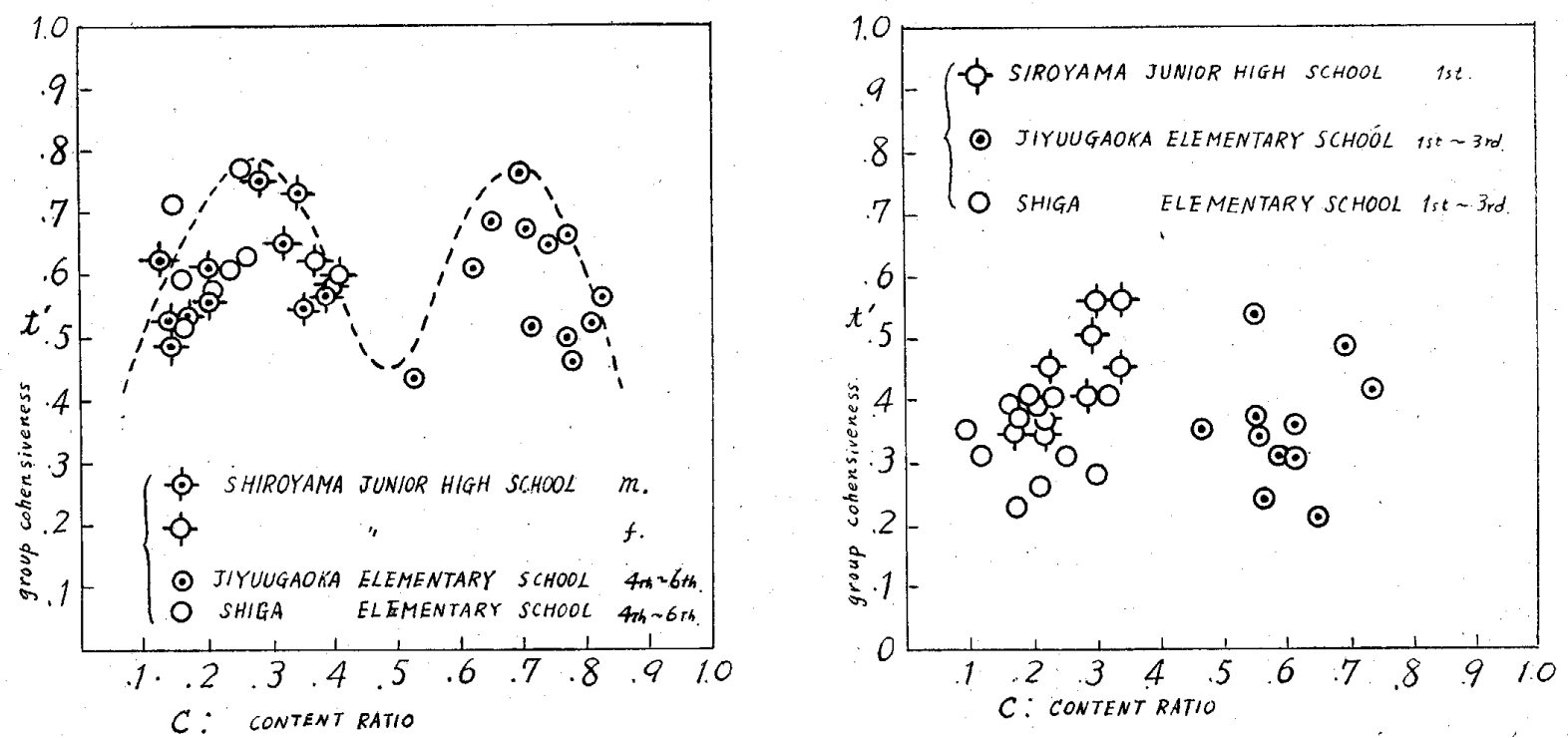

Fig. 9. Group cohesiveness and content ratio of children of new housing in one class. 


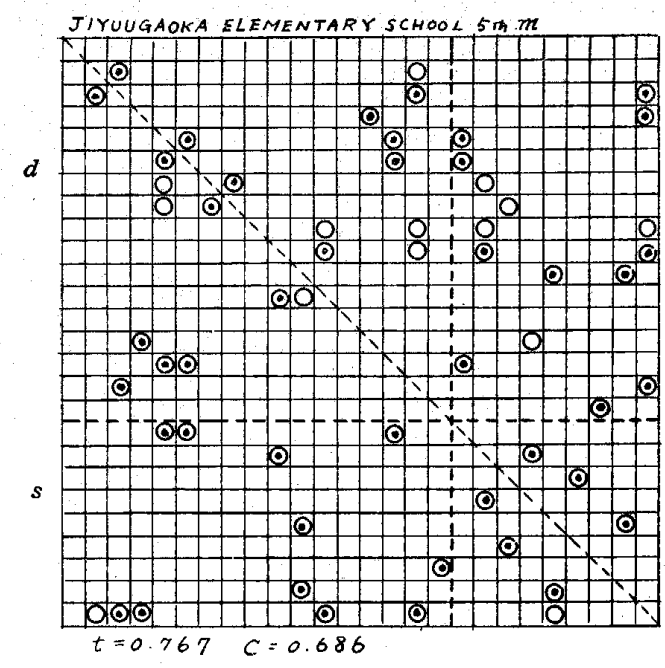

Fig. 10

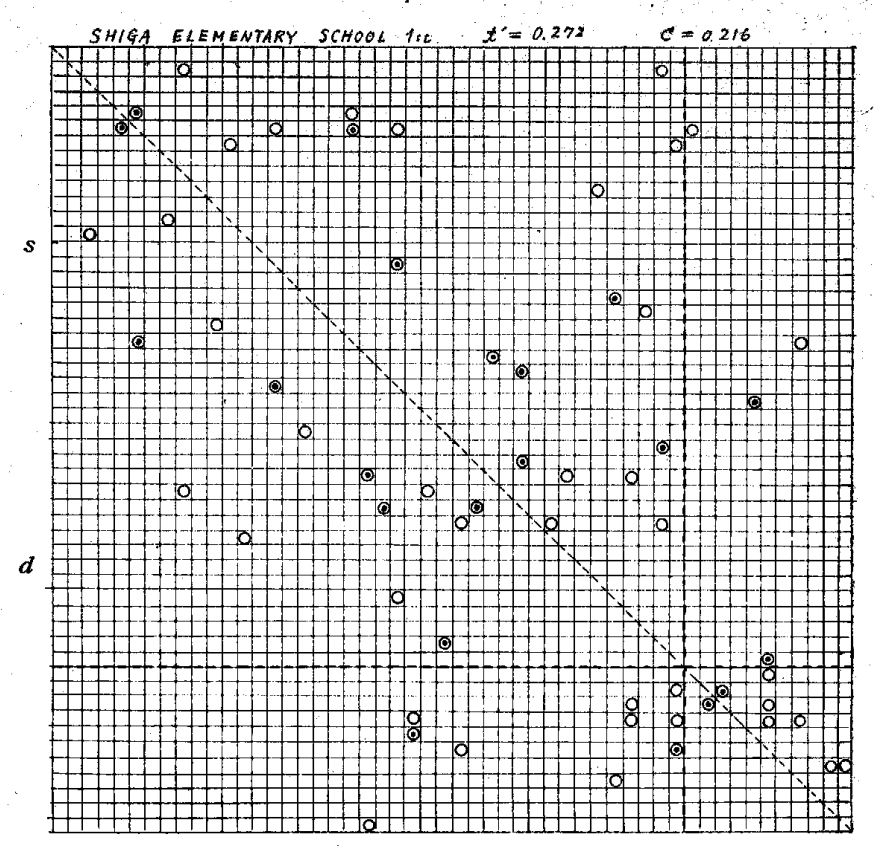

Fig. 12

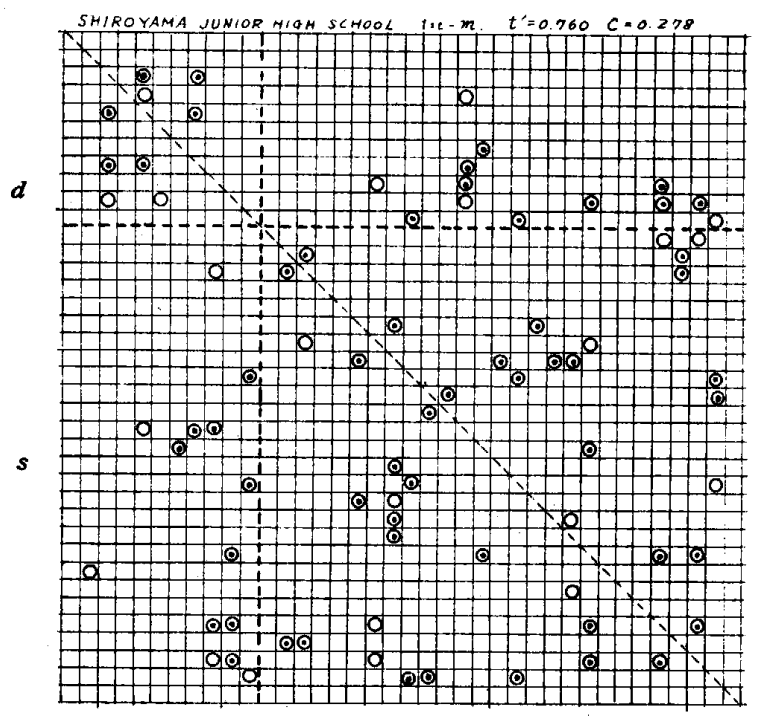

Fig. 11

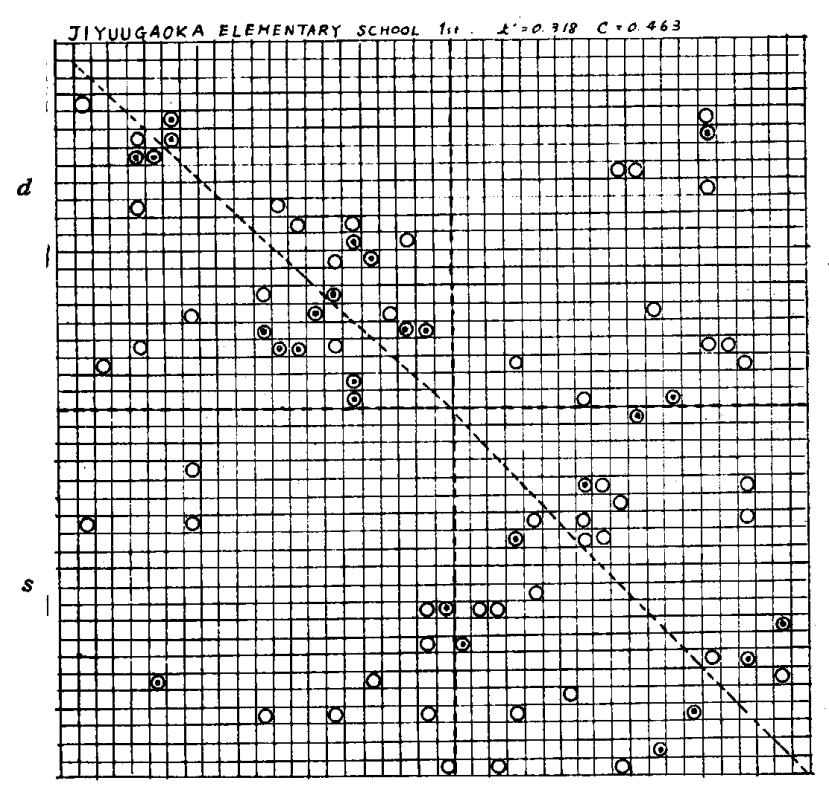

Fig. 13

Fig. 10 13. Sociometric matrix of one class.

lower classes does not show the tendency clearly.

In this case, it does not always mean the homogenious group cohesiveness that " $t$ " " value is high, but " $t$ " value will be occasionally risen by the polarization of each group including children of the both districts for by group of same sex.

Tring to consider the real examples about friends selection of each class, they are shown by sociometric matrix as a Fig. 10 13, and here the considerable to be a high value of " $t$ " "for a standard value " $t$ " " will be found as follows.

1) There are many numbers of selection in sociometric matrix and especially in the ratio of mutual selection and in general they are mixed. (Fig. 10)

2) In the case of sexual discrimination, it is recongnized the groups of children of only one housing being isolated from the group of children of the other housing. (Fig. 11)

3) There are examples that the children of the new housing are selected by their friend or select their friends but are making their group including the children of its environs. and etc.

In opposition, about low value of " $t$ " " 
1) In general, there are not many numbers of selections especially in mutual selection. (Fig. 12)

2) Though there are many number of selections there are not many mutual selections and they are unilateral selections and heterogeneous scatterings in matrix. (Fig. 13)

3) Sometimes children of new housing are selected unilateraly by their friends. and etc.

It is considerable that the influence force of children of new housing and its environs in a class is feeble almost at under $C \doteqdot 0.2$ or upper $c \doteqdot 0.8$, and they will be found as same character of a class as a general primary school (not mixed school), and group cohesiveness normal value at " $t$ "'.

From the point of view of the above analysis, it seemes that the scatter of association of friendship in one class will be cohensive and the suitable conditions at content ratio $0.3<C<0.7$ in case of higher school years and $C>0.5$ in case of lower school years except the unknown communications between boys and girls in one class.

\section{\$ 4. Some investigation on the influence zone in respect of the density of houses}

Just as the result of $\S 3$, the content ratio of pupils of the new housing and old one class will be concerned with the number of houses in new housing and its environs, which area must be within 0.5

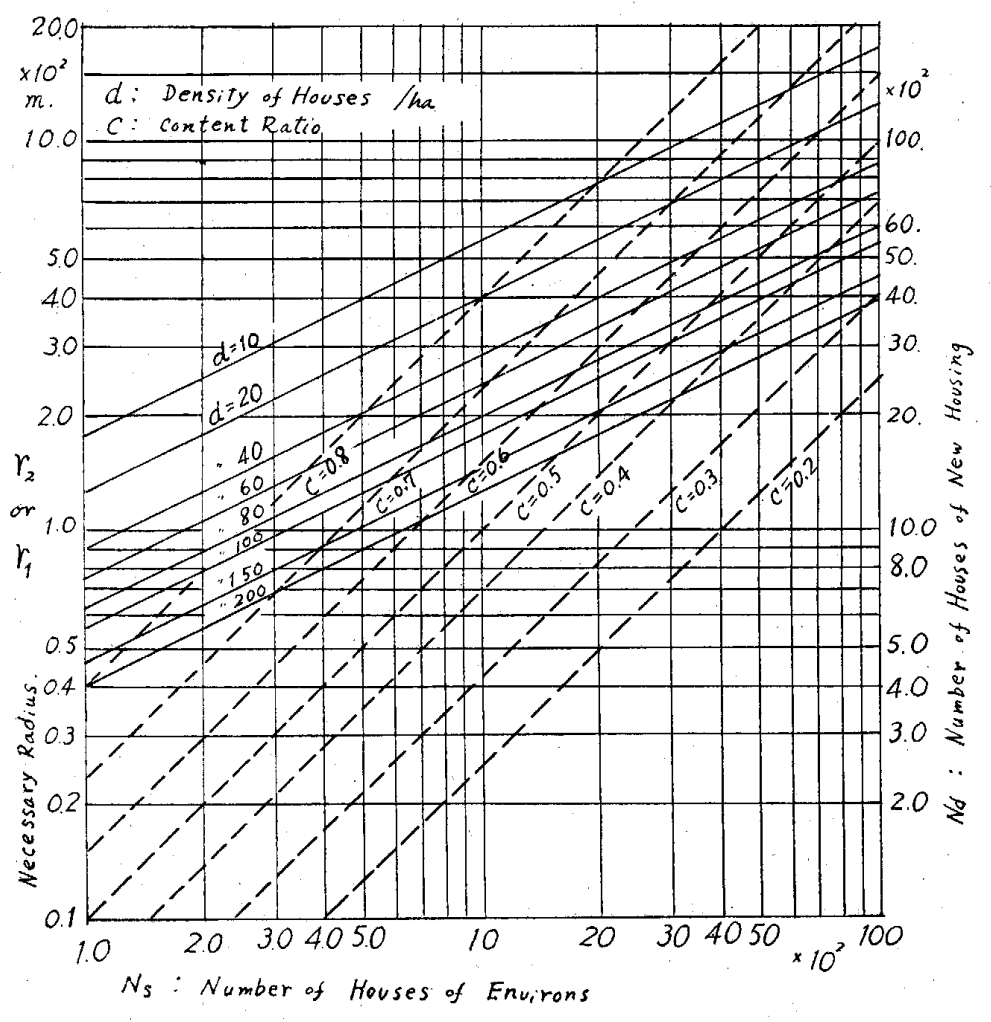

Fig. 14. the total number of houses and necessary radius for its area. $\sim 1.0 \mathrm{~km}$ on foot. In general, if density of the number of houses are decided, the relation between the total number of houses and necessary radius for its area will be difined directly that is

$$
N=\pi d r_{2}{ }^{2}
$$

wherein $N$ : Total number of house

$d$ : Density of number of houses

$r_{2}$ : Necessary radius for its area And these relations are shown by Fig. 14. Then, for taking up the relation between the number of houses of new housing and its environs, the area of environs of new housing should be correct the radius of equivalent area of the new housing. And it will be as fo llows. (but $r_{1}<r_{2}$ )

$$
\Delta r=\pi\left[\sqrt{r_{2}^{2}+\frac{r_{1}^{2}}{\pi}}-r_{2}\right]
$$

Wherein $\Delta r:$ Radius distance to be added to the radius

$r_{1}$ : Radius of equivalent circle with the new housing.

If it is applied on Shiga Housing with this formula, it is as follows (but supposing that the case of about same persentage of school attendance and of children in one family).

$N=1200$ houses, $d=125$ houses/ha, $r=175 \mathrm{~m}$

$d s^{\prime}=30$ houses/ha That is density of house in the environs of new housing.

If content ratio were $C \doteqdot 0.7(D: S=2: 1) N_{s}=600$ houses

hence $r_{2}=260 \mathrm{~m}$ and therfore $\Delta r_{2}=57 \mathrm{~m}, r_{2}+\Delta r_{2}=317 \mathrm{~m}$

If content ratio were $C \div 0.3(D: S=1: 2) N_{s}=2400$ houses

hence $r_{2}=520 \mathrm{~m}$ and therfore $\Delta r_{2}=25 \mathrm{~m} \quad r_{2}+\Delta r_{2}=545 \mathrm{~m}$

However if in a large scale housing or town ( $=50000$ population), the influence zone of environs to one elementary school and junior high school will be only semi-circle, and this correct value are nearly equal

$$
\Delta r_{2}^{\prime}=0.468 r_{2}^{\prime}
$$

For example, appling on Chigusadai Housing 

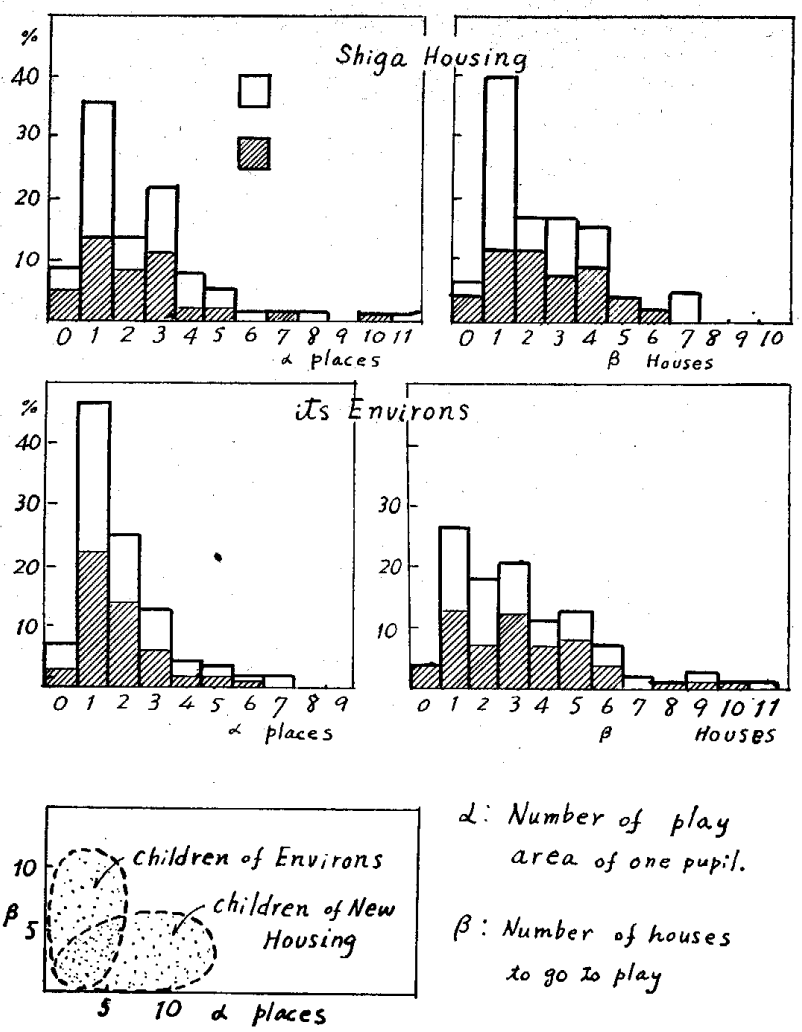

$\alpha$ : Number of play area of one pupil.

$\beta$ : Number of houses to go to play

Fig. 15. Play areas and houses to go to play,

\section{$\S$ 5. On the play zone for children}

It is thinkable that the relation of number of play places and number of play fellow will very depend on the physical environments of its neigourhood.

Namely, as for recreation places of children there are several cases as follows, at the out-door space (play lot, play area, garden, road, square and park etc.) and at the in-door space (home of themselves or friend). Hence the former will be influenced by the character of out door space that is land use ratio of park, road, and green area, house density, plentifulness of public facilities etc., the latter will be infuenced by the number of selections of friends, depth of friendship, possibility of playing in the house etc.. In distinction of pupil, the mutual raltion of play by children at out door space and indoor space (include the home garden) is as Fig. 15 -case of Chigusadai Housing.

Then the Fig. 15 shows that children of new housing show their stronger tendency for playing to go to the out door space in new housing than the playing in the frineds's house. On the other hands, the children of its environs often visit thier friends's house but very little to go to play at the out door space.

Hence, these phenomena are shown as the typical pattern Fig. 15. Then, the tendency of children of new housing correspond with the length-type scattering and children of housing of its environs correspond with the width-type scattering, but there is no difference between both sexes. The number of play area and friends of junior high school girls of new housing are generally small, and the girls of housing of its environs have about the same persentages for going out to play at the out door and for visiting their friends's houses for playing, as Fig. 15 scattering shows.

As above mentioned, children of new housing have the tendency to play at out door spaces, but children of old housing of its environs have tendency to play at their friends's home garden. It seemes that these two different characters depend on the difference of dimensions of houses, ratio of road, ratio of park and play area, in new housing and old housing. In the case of Chigusadai Housing and its environs, it seemes that the reason of the difference between both districts being not clear depends on the scale of housing, namely as this housing is very big, so there is little different enviroment between both housing.

Accordingly, if it is desirable to be corresponded with the both ratio in scattering type of children, the children of old housing should come more into the new housing area or children of new housing should go out to old housing area. From the total point of view of the planned housing, it is desirable 

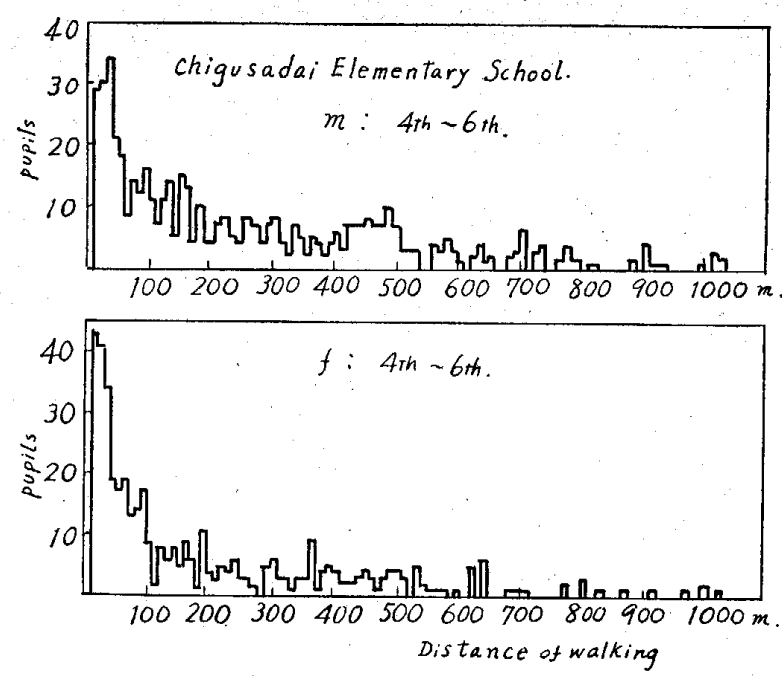

Fig. 16. Play zone of walking and its number of pupils. that children of old housing use more positively the out door space of new housing. And nowadays, it has being able to see this tendency in actual. Fig. 16 shows the maximum walkable space as a play zone by pupils of elementary school. The play zone of children is about $1 \mathrm{~km}$ radius and number of pupils decreases in proportion to the distance of walking with exponential curve.

In case of children of higher school years in a primary school it is a remarkable point that distribution curve has one peak group in $400 \sim 500 \mathrm{~m}$ zone, and it also means that they have their zone in $500 \mathrm{~m}$, and also have their zone in $70 \mathrm{~m}$ near their houses.

From the point of analysis of the ratio of distribution distnace, $40 \%$ or less of all boys play at $100 \mathrm{~m}$ zone about $50 \%$ or more of all girls play at this

zone. And girls have not one peak at $400 \sim 500 \mathrm{~m}$ zone. Hence, on the occasion of the planning of boys park at $500 \mathrm{~m}$ zone, the dimention, number of park and character of instruments of play shoud be considered with above mentioned conditions. According to some previous studies of writer, in actual though $30 \%$ of children of environs invade to new housing for playing, the number of children of new housing who advance to environs are only about a half numbers of children who invade to new housing.

\section{§ 6. Conclusion}

Concluding the above main studies, it is as follows.

1) From the point of view of the selection of friend in one class, it seemes that the content ratio of the children of new housing $0.3<C<0.7$ are the suitable standard as the portion pupils organizing a class of higher school years of an elementary school and junior high school which will be built in the new housing, but $C>0.5$ in case of lower school year.

2) It shoud be considered the contents of facility in the park in $500 \mathrm{~m}$ zone, as the utility by girls decrease very much.

3) From the point of view the character of friendship and the play children of the new housing and its environs, the new housing has an enough possiblity to be a center of community in a large area of its environs. 


\title{
住宅団地の小中学校計画に関する基礎的研究
}

\author{
正会貣 谷
}

汎 邦*

\section{§1.まえがき}

大規模な住宅団地やニュータウンの建設にあたっては 多くの公共的施設が必要であるが小中学校は特に重要な るのの一つである。現在我が国の中大規模住宅団地は大 都市近郊またはその周辺に計画されるととが多いがその 計画に際しては団地附設小中学校か沺地生徒児童のみで 運営されることは少く，既存の地域社会の児童生徒を収 容せねばなら機会が多い。また，たとえ大規模な二ュ 一タウンであっても，周辺にある地域会社と全く無関係 に計画を行うことは好ましくない。特に教育関連施設は 地域社会間の交流発展の核としての役割をはたす可能性 のあるものとして団地計画の重要な設計条件の一つとし て加光られることが望ましい。この研究は上記の如き問 題に注目し，新住宅団地の小中学校の計画に際して団地 児童, 生徒と既存の学校区の児童生徒の数的関係をどの 程度にすることが適当であるかについて，主として学級 集団を中心とした児童生徒の交友選択の性格およびそれ に関連した地域における就遊等の面加らてれを把えた研 究であり既報の研究にさらに新しい事項を加えて検討を 行ったものである。すなわち，各学校別の学級生徒児童 （第一表）に対して，友人選択とその性格，就遊圈域打 よび成績・評価（教師の）等が調查された。

\section{§ 2. 学級における生徒児童の友人選択について}

生徒・児童の友人遙択動機は日常生活構造の種々の点 が原因となるが学級沈引る友人選択はその主要な部分 を占めている。ての調查においては，学級集団を主体と した選択範团，約数名の自由制限において友人選択を行 なわせ男女別にみて大略の Fig. 1 の如き選択分布比率 であるととが示された。一般にての様な $N$ 人よりなる 集団人選択（制限数 $r$ 人）において，その選択が全くラ ンダムに行われるものとすれば集団内の成員が度 $r$ 人 から選択される確率は第 (1) 式の如くであるから一般 に $r$ 人から選択される確率はその和 $(r=1,2 \cdots r)$ として 示される。

この一例を算定して, 実際の学級別分布比率と対応させ るならば，かなりの相違が認められる。てれは一般に集 団成員の個人が受ける選択数か㵍題となる 場合の標準 的検定法として考えられている。本研究の場合にはか なりの性格的相量（社会階級的・文化的・生活的）のあ るものと予想される二つの集団の混合グループを取扱う べく，同様の考光方でてれを一人の成員の選択によって 作られる個々のグループ群の問題として考えるならば， まづ $N_{d}$ 人の団地児を含む $N$ 人からなる学級内で $r$ 人

* 東京工業大学理工学部 助手

(昭和 38 年 2 月末本稿受理，討論期限 9 月末）
の自由制限においてつくられる選択グループ内に団地児 童生徒の含まれる確率密度は一般に第 3 式の如くに近似 出来る。乙れを実際の分布と比較するならば Fig. 2 の 如く相違がある。この両者の平均值の差を $(\Delta V)$ とし て，乙れと一学級に含まれる団地児数比率 $C=N_{d} / N$ （混合比）の関係をみると Fig. 3 の如くでCの増大と $\Delta V$ の増大は大略直線带的である。すなわち 1 学級内に いる団地児数の增大は，より大きく理論分布と差異を生 じさせて扝り, 混合学級の象徴的選択傾向を示すものと 考えられる。

\section{§3. 1 学級における児童の混合比亡疑集性について}

前章で述べた性格を別の面から検討する。一般に学級 に扔ける教育では倜々の生徒・児童の水準を集団的効果

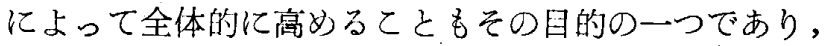
その場合児童・生徒間の相互影響は大切な事項となる。

との様な一学級における選択影響の分布を测定するも のとしては Sociometric Matrix もこの一つである (Fig. 10 13)。

今との一学級マトリックス内を罒地児と周辺児のグル ープによって仮に区画するならば次の如く（Fig. 5)

$(d-d)$ 領域：団地児が河地児を選択する場合の領域

( $d-s)$ 領域：団地児が周辺児を選択する場合の領域

$(s-d)$ 領域：団地児が周辺児を選択する場合の領域

$(s-s)$ 領域：周辺児が団地児を選択する場合の領域 の四つとなり，選択によって示されるマーク（O印） はこのすべての領域またはいくつかの領域佂必ず分布さ れる。

もし集団成員数が比較的大きく且交友選択が極めて数 学的にランダムに行われるものとすればその分布比率は 各領域の選択分布可能数の比率と略々一致するものと考 えることが出来る。すなわちこれらは団地児の混合比に よっているものであって第 4 式の比となる。ての比率分 布を図示すれば (Fig. 4) の如くになり同時にての図上 に実測のマトリックス（学級別）加ら求めた各領域に存 在する○印の比率分布を記入することが出来る。との分 布について次の事が認められる。(Fig. 4)

1） $(d-d)$ 領域の分布は $95 \%$ 沙理論分布曲線上りも 高い值を示している。特に $C<0.5$ の場合において 高い。

2） $(s-s)$ 領域の分布は一般に 理論值を中心に比較的 自然な分布である。しかし $C<0.2$ では理論值より も高いものがある。

3） 1)および 2) の性格の関数関係において $(d-s) お$ よび $(s-d)$ 領域分布は一般に理論值よりもほとんど低い 值である。特に $C<0.5$ でその性格が強い。1）はマト 
リックス内の分布において団地坚が団地児を選択する傾 向が常に強いととであって，内部分布が Fig. 5 の示す 如くなの方向に集中するてと意味している。特に $C \div$ 0.3 でその力は強くグループ化しやすいことを示す。ま たCの值が高くなるにつれてその傾向は弱まっている。 特に周辺先はランダムな選択傾向か強い。このマトリッ クス分布の型を分類するならば次の如くである。(Fig. 5)

a）均一型，b）同属集中型，c）ヨコ分布型，e）タテ 分布型，d）他属集中型である。

各小学級の分布をての型で分数するならば Fig. 6 の如 くで最も多いものは，b）型（団地児同士）で全体の60\% 近くを占め次いで c) ヨコ型が多い。中学校についても 大略以上と同じ傾向を示している（図略）

さて，集団成員による一つの集団の凝集性（結び付の強 さ，集団のもつ魅力）を数量的に示すものとしてソシオ メトリーにおいては,いくつかの提案がある(第 $5 \sim 8$ 式) Katz-Powell の方法（第 8 式）もその一つである。ての 式の $t^{\prime}$, 值 $\Sigma r_{i}$ (選択数合計) $m$ (相互選択数) の関係 孝成員数 $N=40$ 人の場合について筆者の算定によると Fig. 7 の如くであり $-1 \leq t^{\prime} \leq 1$ の間の $m$ と $\Sigma r_{i}$ と の関係の一般的性格党理解出来る $(N=10,20 \cdots 60$ につ (ては図略)

これより学級別に $t^{\prime}$ 值を求めると，小学校の場合学年 の上昇と共にこの值が一般的には上昇するとと㹥普通小 学校 (Fig. 8) と同様であるが沺地小学校では 1 3 年 と 4 6 年で急激な $t^{\prime}$ 値の差異か認められた。これは団 地児の入居経年にも関係する事項ではあるが周辺児と団 地児の混合学級の児童の成長発育に伴う特性として注目 しなければなら点でもあらう。中学校の場合には学年 による上昇は顕著ではない。次に $t^{\prime}$ 值と混合比の関係を みると小学校高学年と中学 3 年の場合は Fig. 9-1 の如 く $C \doteqdot 0.3$ および $C=0.7$ 付近で極大值を示す波型の分 布傾向を示し特に $C \leq 0.3$ 以下では $t^{\prime}$ 值は急激に低下す る。しかし低学年でての傾向は全般に明確ではない。 （Fig. 9-2）乙の $t^{\prime}$ 值の高くなる場合としては，「マ トリックスにおける選択度が一般に多く，特に相互選択 の比率が高い。」 etc. 凝集值の低い場合としては「選択 数が普通であっても相互選択数 $m$ が少い。団地児がー 方的に選択されている」 etc. がある（Fig. 10〜13）

以上の如く現状の混合等級では一般的に団地児が学級の 中の交友選択において象徵的な位置を占める傾向があ り，学級内の凝集力を高力る原因となっていると考えら れるが学級における団地児のグループ化が $C \doteqdot 0.3$ で行
われやすい点, また学級内の值が $C \div 0.3$ および $C \doteqdot$ 0.7 付近で高まる点等からみて, 中学校および小学校高 学年においては一学級における団地児の混合割合として は $0.3<C<0.7$ の範囲が望ましいと思われ，低学年と しては凝集值の関係はあまり明瞭ではないが通学圈（後 述）からみて $C>0.5$ 位が適当と考光る。

\section{\$ 4. 周辺住区の密度と通学圈域等の検討}

前述の如き学級内混合比率にした場合, 団地と周辺の 戸数密度の相違によって, 周辺児の通学影響が決定され る。一般に所定の戸数が含まれる領域を大略半径 $r$ の円 と見做したならばその半径は戸数密度によって一義的に 定められる。もしてれを大略 $r_{1}$ なる円と等洒の小中規 模団地に適応すれば学級混合比によるその周辺の影響圈 半径は第15式およびその修正值（第10式）の和として示 される。また大規模団地の場合にはその団地に接した大 略半冈形をその団地への通学影響圈として修正式第 11 式が得られる。上記の戸数密度と領域半径の関係並びに 混合比の関係を示すならば Fig. 14 の如くで大略の影響 圈を知るととが出来る。すなわち混合比の決定は同時に 周辺戸数密度との関係を考慮に入れるべきことが当然必 要となる。

\section{§5. 归童・生徒の就遊圈域について}

団地児之周辺児では日常の遊びてついての性格・内容 が異ることが明らかとなった。すなうち団地児は遊び場

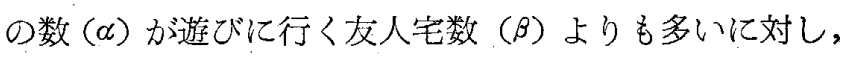
周辺児は遊びに行く友人宅数の方が多く，両者が逆の比 率となっていることである (Fig. 15) この相違は是正さ れるととが望ましくその為に周辺児の積極的な団地誘致 も考光られてよい。また就遊距離については男女別（高 学年の場合) にみて常識通り男子の方が遠距離進出であ り，女子の方は男子より近距離進出の傾向であるが男子 の場合に $\div 500 \mathrm{~m}$ 付近で一つのピークがあるととは公園 計画に際して注意すべき点と考えられる。(Fig. 16)

本論文に直接関連した既報論文

$1^{\circ}$ 住宅団地々隣接小学校について その 1 4 日本建築学会関東支部研究発表会梗概 集 $35.1 \sim 6$

$2^{\circ}$ 住宅団地と隣接小学校に関連した

2,3 の問題 日本建築学会論文報告集 66 号 35.10

$3^{\circ}$ 住宅団地々隣接中学校林 日本建築学会関東支部研究会梗概集 37.6

$4^{\circ}$ 住宅団地と小中学校について 日本建築学会学術講演会要旨 37.10 